\title{
PENDIDIKAN KARAKTER DAN GAYA BELAJAR DALAM PEMBELAJARAN KALKULUS
}

\author{
Dwi Lestari \\ Jurusan Pendidikan Matematika FMIPA UNY \\ Jl. Colombo No 1 Karang Malang Depok Sleman, Email: dwilestari@uny.ac.id
}

\begin{abstract}
ABSTRAK
Penulisan artikel ini bertujuan untuk mengetahui beberapa gaya belajar peserta didik yang diintegrasikan dengan pendidikan karakter. Berbagai upaya dikembangkan dan dilaksanakan dalam rangka implementasi pendidikan karakter pada suatu pembelajaran. Pembelajaran matematika menjadi salah satu sarana pembentukan karakter peserta didik melalui pembelajaran dengan model atau strategi pembelajaran, media atau bahan ajar, dan gaya belajar tertentu. Pada artikel ini akan dibahas mengenai beberapa gaya belajar peserta didik dalam pembelajaraan kalkulus diintegrasikan dengan pendidikan karakter. Dalam hal ini, karakter yang berkaitan adalah religius, jujur, disiplin, peduli, hormat, dan tanggungjawab. Gaya belajar yang berbeda dari peserta didik dapat menjadi aspek pembentukan karakter dalam pembelajaran. Beberapa gaya belajar didasarkan pada tingkat kesenangan peserta didik terhadap proses konkret ke abstrak atau aktif bereksperimen ke observasi reflektif. Dengan adanya variasi tersebut, proses pembelajaran kalkulus perlu difasilitasi dengan baik sehingga dapat membentuk karakter peserta didik yang lebih baik.
\end{abstract}

Kata kunci: pendidikan karakter, pembelajaraan kalkulus, gaya belajar

\begin{abstract}
This article aims to determine some learning styles of students are integrated with character education. Various efforts are developed and implemented in the framework of the implementation of character education in a study. Learning mathematics be one key of character formation of students through learning with models or learning strategies, media or teaching materials, and specific learning styles. In this article we will discuss some of the learning styles of students in learning calculus integrated with character education. In this case, the characters are related is a religious, honest, disciplined, caring, respect, and responsibility. Different learning styles of students can be character building aspects of learning. Multiple learning styles based on the level of students's pleasure to process the concrete to the abstract or reflective observation to active experiment. Therefore by using that variation, the learning process of Calculus should be well facilitated so that the better character students can be formed.
\end{abstract}

Keywords: character education, learning Calculus, learning styles

\section{Pendahuluan}

Dalam kehidupan berbangsa dan bernegara, pendidikan merupakan salah satu aspek dalam kehidupan manusia yang memiliki peranan penting. Suatu bangsa dapat mencapai sebuah kemajuan dan dapat mengikuti perkembangan teknologi dunia jika pendidikan dalam negara tersebut kualitasnya baik. Proses membangun sektor pendidikan tidak akan pernah mencapai tujuan akhir yang sempurna. Hal ini terjadi karena konteks 
pendidikan selalu dinamis, berubah, dan tidak pernah konstan, sesuai dengan perubahan masyarakat, ilmu pengetahuan, dan teknologi.

Seiring perkembangan ilmu pengetahuan dan teknologi, tantangan untuk generasi penerus pada masa yang akan datang semakin besar. Sementara itu, untuk mencapai pendidikan yang berkualitas baik perlu dibangun generasi penerus yang berkarakter baik. Undangundang No 20 Tahun 2003 Tentang Sistem Pendidikan Nasional pada Pasal 3 menyebutkan bahwa : "Pendidikan nasional berfungsi mengembangkan kemampuan dan membentuk karakter serta peradaban bangsa yang bermartabat dalam rangka mencerdaskan kehidupan bangsa". Dalam hal ini, langkah yang dapat ditempuh adalah melalui pembelajaran yang mengintegrasikan pendidikan karakter. Pendidikan karakter sekarang ini mutlak diperlukan bukan hanya di lembaga pendidikan saja, tetapi juga di rumah dan di lingkungan sosial. Saat ini, peserta pendidikan karakter bukan lagi anak usia dini hingga remaja, tetapi juga usia dewasa. Hal ini menunjukkan bahwa pendidikan karakter diperlukan untuk kelangsungan hidup bangsa Indonesia (Ida, 2012).

Pendidikan karakter perlu dilakukan secara terintegrasi ke dalam semua mata pelajaran. Menurut Aning
(2012), pada dasarnya kegiatan pembelajaran selain untuk menjadikan peserta didik menguasai kompetensi (materi) yang ditargetkan, juga dirancang dan dilakukan untuk menjadikan peserta didik mengenal, menyadari atau peduli, dan menginternalisasi nilai-nilai dan menjadikannya perilaku. Oleh karena itu nilai karakter seperti religius, tanggungjawab, disiplin, peduli, hormat, percaya diri, dan jujur dapat terbentuk melalui pembelajaran. Lebih lanjut bahwa integrasi pendidikan karakter dalam pembelajaran ini dimulai dari Tingkat PAUD, SD, SMP, SMA sampai Perguruan Tinggi.

Dalam pembelajaran di Perguruan Tinggi, mata kuliah kalkulus merupakan salah satu mata kuliah dasar sehingga pembelajaran kalkulus berlangsung di awal peserta didik masuk Perguruan Tinggi. Integrasi pendidikan karakter di awal akan sangat mendukung untuk keberlanjutan studi khususnya mata kuliah kalkulus yang juga menjadi mata kuliah prasyarat. Dalam proses pembelajaran, sangat dimungkinkan adanya perbedaan gaya belajar peserta didik. Namun demikian dengan pemberian fasilitas saat proses pembelajaran dapat menumbuhkan karakter peserta didik melalui pembelajaran kalkulus. 


\section{Metode Penelitian}

Penelitian ini akan membahas mengenai pendidikan karakter pada proses pembelajaran, dilanjutkan dengan membahas tentang pembelajaran Matematika. Setelah itu akan dibahas mengenai gayaa belajar peserta didik yaitu mahasiswa. Penelitian diakhiri dengan pembahasan mengenai karakter dan gaya belajar alam pembelajaran Kalkulus.

\section{Hasil dan Pembahasan}

\section{Pendidikan Karakter}

Secara definitif dapat dikatakan bahwa karakter merupakan nilai-nilai perilaku manusia yang berhubungan dengan Tuhan Yang Maha Esa, diri sendiri, sesama manusia, lingkungan dan kebangsaan yang terwujud dalam pikiran, sikap, perasaan, perkataan, dan perbuatan berdasarkan norma-norma agama, hukum, tata krama, budaya dan adat istiadat. Pendidikan menjadi salah satu wahana utama untuk mengembangkan karakter tersebut (Ida, 2012).

Menurut Kamus Besar Bahasa Indonesia, karakter adalah watak, tabiat, akhlak, atau kepribadian seseorang. Karakter terbentuk dari hasil internalisasi berbagai kebajikan (virtues) yang diyakini dan digunakan sebagai landasan untuk cara pandang, berpikir, bersikap, dan bertindak. Interaksi seseorang dengan orang lain menumbuhkan karakter masyarakat dan karakter bangsa (Direktorat Pembinaan SMP, Panduan Pendidikan Karakter di SMP, 2010).

Menurut Tatag (2012), bahwa karakter merupakan suatu kumpulan karakteristik individu yang khas dalam berpikir, berperilaku, dan bertindak dalam hidup, bergaul, bekerjasama, maupun memecahkan masalah di lingkungannya. Karakteristik tersebut dapat berkaitan dengan aspek psikologis (seperti bawaan, emosi, kepribadian, budi pekerti, sifat, tabiat, temperamen, atau watak), aspek moral (berupa nilai-nilai yang disadari dan diyakini), dan aspek kognitif (gaya berpikir, penalaran, ataupun berbahasan). Dengan demikian, karakter sebenarnya tidak hanya berupa nilai-nilai, tetapi juga kemampuan, keyakinan, moralitas, pengendalian emosi dan pengarahannya, serta perwujudan perilaku yang sebenarnya.

Berdasarkan pengertian tentang karakter tersebut, dapat disimpulkan bahwa karakter merupakan suatu perilaku individu yang terwujud dalam pikiran (gaya berpikir), sikap, perasaan, perkataan, dan perbuatan dalam kesehariannya di lingkungan sekitar berdasarkan norma-norma agama, hukum, tata krama, budaya dan adat istiadat. Oleh karena itu, untuk membentuk peserta didik yang 
berkarakter diperlukan pendidikan yang mengimplementasikan karakter di dalamnya. Pendidikan karakter sangat perlu diterapkan dalam sebuah pembelajaran khususnya pembelajaran matematika.

Adapun beberapa nilai-nilai pendidikan budaya dan karakter bangsa sebagai berikut (Ida, 2012):

1. Religius: Sikap dan perilaku yang patuh dalam melaksanakan ajaran agama yang dianutnya, toleran terhadap pelaksanaan ibadah agama lain, dan hidup rukun dengan pemeluk agama lain.

2. Jujur : Perilaku yang didasarkan pada upaya menjadikan dirinya sebagai orang yang selalu dapat dipercaya dalam perkataan, tindakan, dan pekerjaan.

3. Disiplin : Tindakan yang menunjukkan perilaku tertib dan patuh pada berbagai ketentuan dan peraturan.

4. Peduli sosial: Sikap dan tindakan yang selalu ingin memberi bantuan pada orang lain dan masyarakat yang membutuhkan.

5. Hormat: Sikap dan tindakan yang mendorong dirinya untuk menghasilkan sesuatu yang berguna bagi masyarakat, dan mengakui, serta menghormati keberhasilan orang lain.
6. Tanggungjawab : Sikap dan perilaku seseorang untuk melaksanakan tugas dan kewajibannya, yang seharusnya dia lakukan, terhadap diri sendiri, masyarakat, lingkungan (alam, sosial dan budaya), negara dan Tuhan Yang Maha Esa.

Berdasarkan nilai-nilai karakter di atas, pembelajaran matematika pada materi kalkulus diintegrasikan nilai karakter tersebut melalui beberapa kegiatan pembelajaran.

\section{Pembelajaran Matematika}

Pembelajaran merupakan upaya yang dilakukan guru dalam membelajarkan peserta didik untuk melakukan kegiatan yang akan melibatkan peserta didik untuk mempelajari sesuatu dengan cara yang efektif dan efisien. Selain itu peserta didik diharapkan mampu menemukan dan menyelesaikan masalah yang dihadapi dalam pembelajaran yang diberikan.

Dalam makna yang lebih kompleks pembelajaran hakikatnya adalah usaha dari seorang guru untuk membelajarkan peserta didiknya (mengarahkan interaksi peserta didik dengan sumber belajar lainnya) dalam rangka mencapai tujuan yang diharapkan (Trianto, 2010). Dengan adanya proses pembelajaran maka peserta didik mampu 
berpikir kreatif dalam menyelesaikan masalah yang diberikan guru ketika kegiatan pembelajaran dilakukan. Sehingga guru berperan sebagai komunikator, peserta didik sebagai komunikasikan, dan materi sebagai yang dikomunikasikan berisi pesan berupa ilmu pengetahuan (Erman Suherman, 2001).

Selain itu Pembelajaran matematika juga merupakan kegiatan yang telah direncanakan secara sistematis oleh guru matematika, selanjutnya dalam pembelajaran di kelas, peserta didik diarahkan sesuai dengan perencanaan yang telah dibuat, hal ini dilakukan guna mencapai suatu tujuan yang telah ditetapkan, serta mencapai perubahan-perubahan relatif konstan dalam pengetahuan, pemahaman, keterampilan, dan lainnya tentang matematika. Selain itu, pembelajaran matematika perlu menempatkan peserta didik sebagai bagian dari proses pemahaman materi. Adapun materi yang dipelajari perlu diintegrasikan dengan kehidupan seharihari sehingga pembelajaran matematika menjadi bagian kehidupan manusia.

Pembelajaran matematika humanistik, seperti disebutkan oleh (Haglund dalam Tatag, 2012) yaitu:

1. Menempatkan peserta didik sebagai penemu (inquirer) bukan hanya penerima fakta-fakta dan prosedurprosedur;

2. Memberi kesempatan peserta didik untuk saling membantu dalam memahami masalah dan pemecahannya yang lebih mendalam;

3. Belajar berbagai macam cara untuk menyelesaikan masalah, tidak hanya dengan pendekatan aljabar;

4. Menunjukkan latar belakang sejarah bahwa matematika sebagai suatu penemuan atau usaha keras (endeavor) dari seorang manusia;

5. Menggunakan masalah-masalah yang menarik dan pertanyaan terbuka (open-ended) tidak hanya latihan-latihan;

6. Menggunakan berbagai teknik penilaian tidak hanya menilai peserta didik berdasar pada kemampuan mengingat prosedur-prosedur saja;

7. Mengembangkan suatu pemahaman dan apresiasi terhadap ide-ide besar matematika yang membentuk sejarah dan budaya;

8. Membantu peserta didik melihat matematika sebagai studi terhadap pola-pola, termasuk aspek keindahan dan kreativitas;

9. Membantu peserta didik mengembangkan sikap-sikap percaya diri, mandiri, dan penasaran (curiosity); 
10. Mengajarkan materi-materi yang dapat digunakan dalam kehidupan sehari-hari, seperti dalam sains, bisnis, ekonomi, atau teknik.

Beberapa ciri yang diungkapkan Haglund tersebut sebenarnya mengarah pada ciri-ciri pembelajaran yang menekankan pada nilai-nilai karakter. Nilai tersebut seperti ingin tahu, suka menolong, pemecah masalah, kerja keras, tertantang, apresiatif, kreativitas, percaya diri, dan mandiri.

\section{Gaya Belajar}

Dalam proses pembelajaran, peserta didik memiliki gaya belajar yang berbeda-beda. Gaya belajar ini muncul didasarkan pada tingkat kesenangan peserta didik terhadap proses konkret ke abstrak atau aktif bereksperimen ke observasi reflektif (Knisley,2002). Menurut Kolb, experiential learning adalah suatu proses dimana pengetahuan hasil dari kombinasi yang berbeda dari menangkap dan mentransformasikan pengalaman. Kita dapat memahami pengalaman dengan dua cara yang berbeda, melalui pengalaman konkret dan konsep abstrak. Kita kemudian dapat mengubah pengalaman dalam dua cara, melalui pengamatan reflektif atau percobaan aktif. (David, 2013)

Gaya belajar model Kolb terdiri dari empat kemampuan (1) Concrete
Experience (CE),
(2) Refletive
Observation (RO),
(3) Abstract

Conseptualization (AC), dan (4) Active Experience (AE). Kemampuan peserta didik ini terlihat dalam beberapa kegiatan. Kagiatan belajar yang dilakukan pada proses pembelajaran matematika materi kalkulus dengan gaya belajar model Kolb dapat dikaitkan dengan nilai-nilai pendidikan karakter.

\section{Karakter dan Gaya Belajar dalam Pembelajaran Kalkulus}

Dalam pembelajaran kalkulus, materi yang dipelajari meliputi materi dasar yang digunakan untuk prasyarat mata kuliah tingkat lanjut. Berikut ini diberikan gambaran kegiatan belajar pada proses pembelajaran kalkulus materi integral dengan model Kolb (Winarno dalam tarmizi, 2009).

Kegiatan Belajar :

\section{Pendahuluan:}

1. Dosen membuka pembelajaran dengan berdoa menurut agama dan kepercayaan masing-masing.

2. Dosen membagi mahasiswa dalam kelas menjadi beberapa kelompok,

3. Tiap kelompok terdiri dari 5 mahasiswa.

\section{Kegiatan Inti}

1. Pelibatan peserta didik

- Dosen memotivasi mahasiswa 
- Dosen menjelaskan materi integral sebagai anti turunan secara singkat

- Dosen memberikan apersepsi kepada mahasiswa dengan berbagai pertanyaan untuk menarik minat mahasiswa dalam belajar.

2. Observasi

- Setiap kelompok diberikan lembar kerja

- Mahasiswa mengerjakan latihan pada lembar kerja berdasarkan gaya belajar masing-masing, yaitu (1) Concrete Experience (CE), (2) Refletive Observation (RO), (3) Abstract Conseptualization (AC), dan (4) Active Experience (AE).

3. Menciptakan Konsep

- Mahasiswa diajak berpikir untuk menemukan konsep rumus dasar integral tak tentu

- Tiap kelompok mempresentasikan hasil proses dan hasil pengamatan tersebut ke depan kelas.

4. Pemecahan Masalah dan Pengambilan Keputusan

- Setelah mahasiswa dapat melakukan kegiatan tersebut, maka untuk memantapkan pengertian tentang menentukan integral tak tentu dosen memberikan tugas untuk dikerjakan mahasiswa secara perorangan.

- Dosen berkeliling membantu mahasiswa yang mengalami kesulitan dalam mengerjakan tugas.

\section{Kegiatan Penutup}

Kegiatan belajar ditutup dosen bersama mahasiswa membuat rangkuman pembelajaran tentang konsep integral tak tentu. Setelah itu ditutup dengan doa.

Dari contoh kegiatan pembelajaran tersebut dapat membangun karakter:

(1) Religius: kegiatan belajar diawali dan diakhiri dengan berdoa

(2) Hormat: dalam kelompok, setiap anggota memiliki perbedaan gaya belajar sehingga diharapkan mampu menghargai dan menghormati hasil pemikiran anggota lain.

(3) Peduli: setiap anggota dalam kelompok saling membantu anggota yang lain untuk dapat memahami materi.

(4) Disiplin: dosen berkeliling membantu mahasiswa dalam mengerjakan latihan, agar latihan dikerjakan dengan gaya belajar masing-masing dan tetap memperhatikan konsep materi.

(5) Jujur: dosen memantau setiap kelompok, diharapkan setiap mahaasiswa yang belum paham 
langsung meminta arahan dari anggota lain yang sudah paham. Apabila setiap anggota tidak paham, kemudian baru menanyakan ke dosen.

(6) Tanggung jawab: setiap kelompok menyampaikan hasil diskusi. Hal ini membangun karakter setiap anggota bersama-sama mengerjakan latihan yang dibebankan untuk kelompoknya.

\section{Penutup}

Pendidikan karakter yang dibangun melalui pembelajaran matematika materi kalkulus ini meliputi nilai religius, hormat, peduli, disiplin, jujur, dan tanggung jawab. Nilai-nilai karakter ini dibangun dengan mengintegrasikan gaya belajar melalui pengalaman konkret dan konsep abstrak atau gaya belajar yang mengubah pengalaman dalam dua cara, melalui pengamatan reflektif atau percobaan aktif. Untuk kajian dan penelitian lebih lanjut diharapkan dalam pembelajaran matematika terintegrasi lebih banyak lagi nilai-nilai pendidikan karakter.

\section{Pustaka}

Aning Wida Yanti. 2012. Aplikasi Pendidikan Karakter pada Pembelajaran Kalkulus. Makalah diseminarkan pada Seminar
Nasional Pendidikan Matematika, Surabaya, 5 Mei 2012

David Saputra. 2013. Teori Belajar Menurut David Kolb (Humanistik). Diakses April 2014 di http://saputradavid.blogspot.com/2 013/04/teori-belajar-menurutdavid-kolb.html

Departemen Pendidikan Nasional. UU No 20 Tahun 2003: Tentang Sistem Pendidikan Nasional. Jakarta: Depdiknas

Departemen Pendidikan Nasional, Kamus Besar Bahasa Indonesia edisi keempat, Jakarta: PT Gramedia, 2008.

Erman Suherman, dkk. (2001). Strategi Pembelajaran Matematika

Kontemporer. Bandung: JICAUPI.

Ida Farida. 2012. Model Pendidikan Karakter di Perguruan Tinggi: Langkah Strategis dan Implementasinya di Universitas. Jurnal Ilmiah Administrasi Publik dan Pembangunan, Vol.3, No.1, Januari - Juni 2012

Knisley, Jeff. 2002. A Four-Stage Model of Mathematical Learning.ERIC Journal articles Mathematics Educator, v12 no.1 p11-16 Spr 2002. Diakses bulan April 2014. 
Tarmizi. 2009. Gaya Belajar Model Kolb. Diakses April 2014 di http://tarmizi.wordpress.com/2009/ 01/01/gaya-belajar-model-kolb/

Tatag Yuli Eko Siswono. 2012. Implementasi Pendidikan Karakter dalam Pembelajaran Matematika. Makalah disampaikan pada Seminar Nasional Pendidikan Matematika "Pengembangan Desain Pembelajaran Matematika Berkarakter”, $\quad$ Sabtu, 24 NOPEMBER 2012 di Auditorium
Prof. Dr. Harun Nasution, UIN SYARIF HIDAYATULLAH JAKARTA

Trianto. (2010). Mendesaian Model Pembelajaran Inovatif-Progresif: Konsep, Landasan, Implementasinya pada Kurikulum Tingkat Satuan Pendidikan (KTSP). Jakarta: Prenada Media Group 
